\title{
A határmentiség és a turizmus sajátos összefüggései Kárpátalja magyarlakła területein
}

\section{Border position and tourism in Subcarpathia}

\author{
BERGHAUER SÁNDOR
}

KULCSSZAVAK: határmentiség, turizmus, Kárpátalja, bevásárlóturizmus, VFR-turizmus ${ }^{1}$

ABSZTRAKT: A határ menti területek sajátos kapcsolatrendszerét számos kutatás taglalta a korábbi években. Az esetek többségében kiderült, hogy határszakasztól függően minden egyes esetben meglehetősen egyedi kapcsolatrendszerről beszélhetünk. Az egyediség jellemzi Magyarország keleti területeinek és az Ukrajna részét képező Kárpátaljának kapcsolatát is, hiszen két meglehetősen eltérő rendszerben fejlődő régió találkozik itt, aminek specifikumát az is fokozza, hogy Kárpátalja határ menti területein nagyszámú magyar ajkú lakos él. A közös határszakasz átlépésének indítékai közül sajátos módon emelkedik ki a VFR-turizmus és az eltérő gazdasági hatások által létrehozott bevásárlóturizmus. Az alábbi tanulmány a szóban forgó határ menti területek utazásokkal, idegenforgalommal összefüggő specifikumait tárja fel.

KEYWORDS: border regions, tourism, Transcarpathia, shopping tourism, VFR-tourism

ABSTRACT: As a result of the agreements and peace treaties in the aftermath of World War l, a sizeable part of both territory and population of Hungary came under the authority of neighbouring countries. The separation from these territories not only divided ethnic areas, but also broke off previously established economic contacts. Peripheral regions developed on both sides of the new borders, and some special zones of attraction began to grow.

Life in the Hungarian border regions became particularly isolated during the Soviet period, though a remarkable number of travels between Hungary and the Ukraine still occurred, motivated by the maintenance of family relationships and friendships (visiting friends and relatives $=$ VFR tourism). Following the collapse of the Soviet Union, the system of contacts within the region changed remarkably, influenced mainly by a fairly one-sided motivation based on purchasing-power differences (initially, with a strong Ukrainian preponderance). After the year 2000, Ukrainian dominance in cross-border traffic declined, and travels in the border region assumed again their former characteristics (visiting relatives, friends and some forex-powered purchasing). Present circumstances provide a much less economycentred, "normal" frame of cross-border traffic.

This kind of specific system of relationships of border regions (often discussed in the pertinent literature) characterises the connections between Transcarpathia (as part of the Ukraine) and the eastern territories of Hungary. In the area mentioned, two regions are having encounters on different levels that develop in fairly different

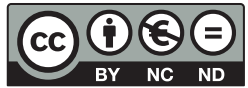


systems. This special position is highlighted by the fact that the border regions of Transcarpathia are inhabited by a great number of ethnic Hungarians. Thus, the motivations of crossing the common border exceed those of both normal shopping tourism (created by different economic effects) and VFR tourism.

The aim of the present study is to reveal the specific processes of development and transformation in the border regions in the last two decades that are connected with travelling and tourism. Searching through case studies, the local peculiarities of shopping trips characteristic of these border regions and VFR tourism which has seen a boom lately, are especially emphasised. Furthermore, we demonstrate the traits and specific features of the travelling habits of the population that lives on the Transcarpathian side of the region.

\section{Bevezetés}

Az I. világháborút lezáró egyezmények következményeként jelentős méretű terület és népesség került Magyarországtól más államok fennhatósága alá. Az ekkor kialakult Kárpátalja (Podkarpatszka Rusz) területén nagyszámú magyarság maradt, és került kisebbségi helyzetbe. A területek leválasztásával nemcsak nemzetiségi területeket szabdaltak fel, de a korábban természetes módon kialakult gazdasági kapcsolatok is megszűntek. A határ mindkét oldalán perifériaterületek alakultak ki, és megindult a sajátos vonzáskörzet-fejlödés. A magyar határ menti térség élete a szovjet időszakban vált különösen izolálttá, de a két ország közötti utazások jelentős részét már abban az időszakban is a rokoni, baráti kapcsolatok fenntartása motiválta. A Szovjetunió széthullását követően a térség kapcsolatrendszere jelentősen megváltozott: egy meglehetősen egyoldalú, jövedelemszerzés-központú motiváció hatása alá került (erős ukrán túlsúllyal). Az ezredfordulót követően mérséklődött a határforgalomban tapasztalt erős ukrán túlsúly, és a korábbról meglévő két mozgatóerő (rokon, barát meglátogatása és jövedelemszerzés) együtt határozza meg a határ menti területek utazásait. A jelenlegi körülmények viszont már jóval szelídebb, civilizáltabb keretet biztosítanak ezek lebonyolítására, a korábbiakhoz képest sokat javult a határok átjárhatósága.

A tanulmány célja, hogy feltárja a határ menti térség területén az utóbbi két évtizedben lezajlott fejlődésnek, átalakulásnak az utazásokkal, idegenforgalommal összefüggő folyamatait. A határ menti térségre jellemző bevásárlóturizmus és az utóbbi időben kiteljesedő VFR-turizmus helyi sajátosságainak a megvizsgálása különös hangsúlyt kap a tanulmányban. Bemutatom továbbá a térség kárpátaljai oldalán élő lakosság utazási szokásainak jellemzőit, specifikumait. 


\section{A magyar-ukrán határ forgalmának alakulása az utóbbi két évtizedben}

Az Ukrajna nyugati kapuját alkotó Kárpátalja négy állammal határos (Lengyelországgal, Szlovákiával, Magyarországgal, Romániával). Geopolitikai helyzete csak az utóbbi két évtizedben vált kedvezővé. A szovjet időszakban erősen korlátozott körülmények között, számos bürokratikus akadály leküzdésével lehetett külföldre utazni. Magyarország területére is csupán egy határátkelőn keresztül vezetett az út (Csap-Záhony). A Szovjetunió széthullását követően elméletileg változott a helyzet, de a mély gazdasági krízisbe zuhanó Ukrajnában nem javultak az életkörülmények, sőt jelentős létbizonytalanság alakult ki. Ennek következtében a határok közelsége felértékelődött. A kárpátaljai háztartások bevételi oldalán fontos tétellé vált a megélhetési turizmus, ami a 20 . század utolsó évtizedében gyakorlatilag lehetetlenné tette a magyar-ukrán határ civilizált átlépését. A helyzet javítása érdekében több átkelőhelyet is nyitottak (Tiszabecs-Tiszaújlak, Beregsurány-Asztély, Barabás-Mezőkaszony, Lónya-Harangláb), de ennek hatására sem javult jelentősen a helyzet, maradt a zsúfoltság és a hosszú várakozási idő (Berghauer 2008, Donka, Gyuricza 2002).

Közvetlenül a rendszerváltás éveiben a határok megnyitásával több mint ötszörösére növekedett az átkelőhelyek forgalma (1. ábra). Ebben az időben nem csak a magyarországi piacok látogatása vált céliránnyá2: sok kárpátaljai lakos Jugoszláviába igyekezett eljutni, vásárlási szándékkal. A határforgalom

1. ábra: A Magyarországra látogató ukrán állampolgárok és az Ukrajnába érkező magyar állampolaárok száma

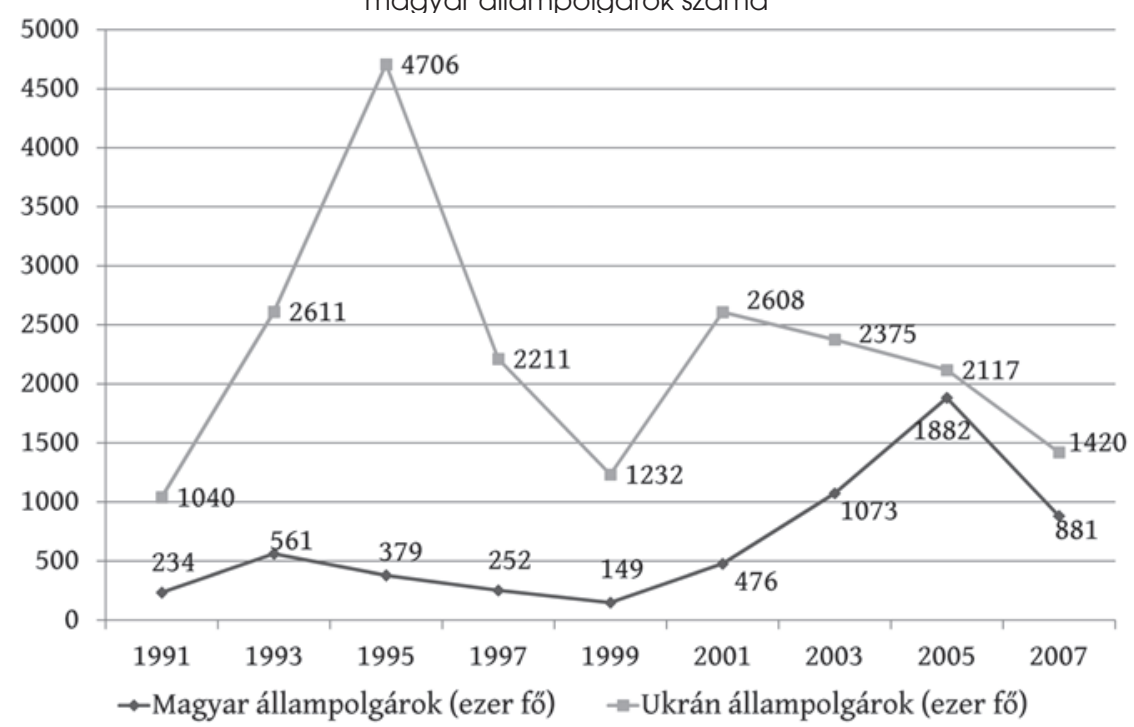

Forrás: KSH 2005, 2007. 
csúcsát az 1995. év jelentette, amely a „Z-turizmus” jegyében zajlott ${ }^{3}$. Ekkor lehetőség volt a szovjet gyártmányú használt gépkocsikat vámmentesen behozni Ukrajnába. Ebben az évben az ukrán állampolgárok 13-szor többen lépték át a közös határszakaszt, mint a magyar állampolgárok. 1996-tól az ukrán hatóságok újabb és újabb szigorításokat léptettek életbe a behozott termékekre vonatkozólag, aminek következtében az 1999-es év határstatisztikai adatai alapján forgalmi mélypont alakult ki. Hasonló forgalomingadozások Magyarország más határszakaszain is megfigyelhetőek voltak (Gyuricza 1996, Balcsók, Dancs 2001).

A határ két oldalán végbement gazdasági, politikai változások sora véget vetett a kialakult megélhetési turizmusnak. Fontos esemény volt ebben a tekintetben Magyarország európai uniós integrációja. Megszüntették a korábban kialakított kishatárforgalmat (napjainkban újraindították), és 2003. november 1-jén bevezették az ukrán állampolgárok vízumkötelezettségét, amelyet 2008. január 1-jétől a schengeni-vízum váltott fel. Az Európai Unió külső határát képező, 137 km-es magyar-ukrán határszakasz szigorú ellenőrzés alá került. Jelentősen megváltozott a határátkelőhelyek arculata, kedvezve a „valós” turisztikai tevékenység kibontakozásának. Ehhez természetesen jelentős gazdasági fejlődésre volt szükség Ukrajnán belül is. A gazdasági élet feléledése, a nyomorküszöbtől való elrugaszkodás, valamint a viszonylag stabillá váló politikai helyzet lehetővé tette a helyi háztartások bevételeinek átalakulását és a csencselőtevékenység felhagyását.

A végbement változások következtében jelentősen megváltozott a határforgalom, kiegyenlítődött a ki-, illetve belépő személyek száma, összetétele. A 2005. év adatait áttekintve láthatjuk, hogy az ukrán állampolgárok már csak tíz százalékkal többen lépték át a közös határt, mint a magyar állampolgárok. A Barabás-Kaszony és Beregsurány-Asztély átkelőhelyeken pedig a magyar állampolgárok tették ki a határforgalom 60-70\%-át. A határforgalom közel 90\%-ára jellemző - mind ukrán, mind magyar részről -, hogy az utasok 24 óránál kevesebb időt töltenek a szomszédos országban, és a kiadások legnagyobb tételét a vásárlás képezi. Az előzmények ismeretében viszont meglepő, hogy míg az ukrán állampolgárok 2005-ben a Magyarországon elköltött pénz 41\%-át fordították vásárlásra, az Ukrajnába érkező magyar állampolgárok esetében ez az érték 75\% volt (1. táblázat) (KSH 2005, Berghauer 2008b).

1. táblázat: Az Ukrajnába látogató magyar és a Magyarországra látogató ukrán állampolgárok kiadásai utazási cél szerint

\begin{tabular}{lccccc}
\hline \multicolumn{1}{c}{ Megnevezés } & $\begin{array}{c}\text { Turisztikai moti- } \\
\text { váció együtt }\end{array}$ & Vásárlás & Munka & Egyéb & Összesen \\
\hline $\begin{array}{l}\text { Magyar állampolgárok } \\
\text { kiadásai Ukrajnában }\end{array}$ & 3664 & 11346 & 47 & 65 & 15122 \\
$\begin{array}{l}\text { Ukrán állampolgárok } \\
\text { kiadásai Magyarországon }\end{array}$ & 5109 & 6902 & 1852 & 2618 & 16480 \\
\hline
\end{tabular}
Forrás: KSH 2005. 


\section{A határ menti bevásárlóturizmus vizsgálata kérdőives felmérés alapján}

A határ menti terület fejlődésében fontos szerepet betöltő bevásárlóturizmus kutatásával ezt megelőzően Kárpátalján nem foglalkoztak. Ennek tudatában fontosnak találtam, hogy kérdőíves felmérés keretei között első lépésként az adott turisztikai tevékenység legjellemzőbb kérdéseire választ keressek ${ }^{4}$. A felmérés - amelynek helyszíneként Beregszász városát választottam - legfontosabb feladata az volt, hogy a bevásárlóturizmus „klasszikus” elemeit (rövid tartózkodási idő, gyakori visszatérés, sajátságos költési struktúra) kimutassa ${ }^{5}$. Már a közvetlen utazási célra vonatkozó kérdésre adott válaszok is jelezték, hogy a bevásárlás a Beregszászba érkező megkérdezettek körében fontos utazási cél. A kifejezetten bevásárlási céllal érkező személyek a forgalom $60 \%$-át képezték, de a rövidebb idejű rokonlátogatás is (25\%) általában bevásárlással párosult.

A Magyarországról Kárpátalja határ menti településeire (10-20 km-es sávba) érkező személyek majdnem háromnegyed része (72\%) a statisztikai kimutatás szerint kirándulóként érkezik a vidékre, és 24 órán belül elhagyja az országot. A rövid tartózkodási idő „tipikusan” a bevásárlóturistára jellemző, hiszen az ilyen jellegü utazás során nem szoktak a célterületen éjszakázni (Michalkó 2002). A hosszabb időre (2 vagy több napra) érkező személyek válaszaiban csak ritkán fordult elő a bevásárlás mint úti cél, de ezekben az esetekben is csak más utazási célokkal együtt.

A rövid tartózkodási időt a bevásárlóturisták gyakori visszatéréssel „kompenzálják”. Az érkezések gyakoriságát tekintve a mintában szereplő legnagyobb csoportot a havonta visszatérők alkotják $(35,7 \%)$ (2. táblázat). Kézenfekvő magyarázat, hogy ezek a személyek rendszeresen itt bonyolítják le havi bevásárlásaikat, illetve előfordulhat az is, hogy rokoni szálak füzik őket a vidékhez. Ezt támasztja alá az utazási célra adott válaszuk is, hiszen az említett 35,7\%-on belül háromnegyed résznyi azoknak az aránya, akik bevásárlói, és megközelítően egyötödnyi a rokonlátogatási céllal Kárpátaljára érkezett válaszadók hányada. A hetente többször $(7,4 \%)$ és a hetente $(10,4 \%)$ érkező turisták utazási cél szerinti megoszlásából kitűnik, hogy 90\%-uk bevásárolni jön. Ez az arány az évente $(7,4 \%)$ és félévente $(11,4 \%)$ Kárpátaljára látogatóknál már fordított módon jelentkezik. A bevásárlást már csak elvétve említik, hiszen esetükben elsősorban a pihenésé, valamint a rokonlátogatásé a föszerep.

2. táblázat: A válaszok megoszlása a "Milyen gyakran utazik Kárpátaljára?” kérdésre

\begin{tabular}{ccccccc}
\hline $\begin{array}{l}\text { Hetente } \\
\text { többször }\end{array}$ & Hetente & Havonta & $\begin{array}{c}\text { Negyed- } \\
\text { évente }\end{array}$ & Félévente & Évente & Egyébáb \\
\hline 7,4 & 10,4 & 35,7 & 19,1 & 11,4 & 7,4 & 8,6 \\
\hline
\end{tabular}

Forrás: saját kutatás. 
A bevásárlóturizmus sajátos kérdései közé tartozik, hogy honnan érkeznek a felmérés alanyai, illetve - ami ebben az esetben fontosabb - mekkora az a távolság, amelyet a bevásárlóturisták még hajlandóak megtenni vásárlási céllal. A tapasztalatok szerint a bevásárlóturizmus vonzáskörzete maximum 130 km-ig terjed, de a Magyarországról érkező személyek bevásárlási céllal átlagosan $54 \mathrm{~km}$ távolságot tesznek meg (2. ábra). A rokonlátogatás céljából érkezők átlagosan $130 \mathrm{~km}$ távolságot tesznek meg, az üdülési/pihenési, valamint üzleti céllal érkező magyar vendégek pedig már 190-200 km távolságról érkeznek (Berghauer 2008a).

A bevásárlóturizmus közvetlenül összefügg az árak, árfolyamok alakulásával. Ilyen tekintetben megállapítható, hogy a kárpátaljai bevásárlóturizmus legforgalmasabb évei a 2005-ös és a 2006-os esztendők voltak. A Kárpátaljára látogató bevásárlóturisták többségét (77\%) a kedvező árak motiválják az itteni vásárlásra. A vásárolt termékek közül a legtöbben élelmiszert (29\%), ruházati cikket (21\%), dohányárut (17\%), alkoholtartalmú termékeket (12\%) vásároltak. Fontos kérdés volt, hogy az elköltött pénz hány százalékát fordították a megkérdezettek üzemanyagra, vagyis hatott-e a kárpátaljai bevásárlóturizmusra a két ország üzemanyagára között tapasztalható különbség. Kényes kérdés lévén, sokan nem válaszoltak (34\%). A válaszok alapján 12,5\%-ról mondható el egyértelmüen, hogy az üzemanyag a fó motiváció, hiszen esetükben a pénz 50-80\%-át benzinre vagy gázolajra fordították. Ezek a személyek

2. ábra: A Kárpátalja határ menti településeire érkező személyek megoszlása utazási cél és megtett távolság szerinti

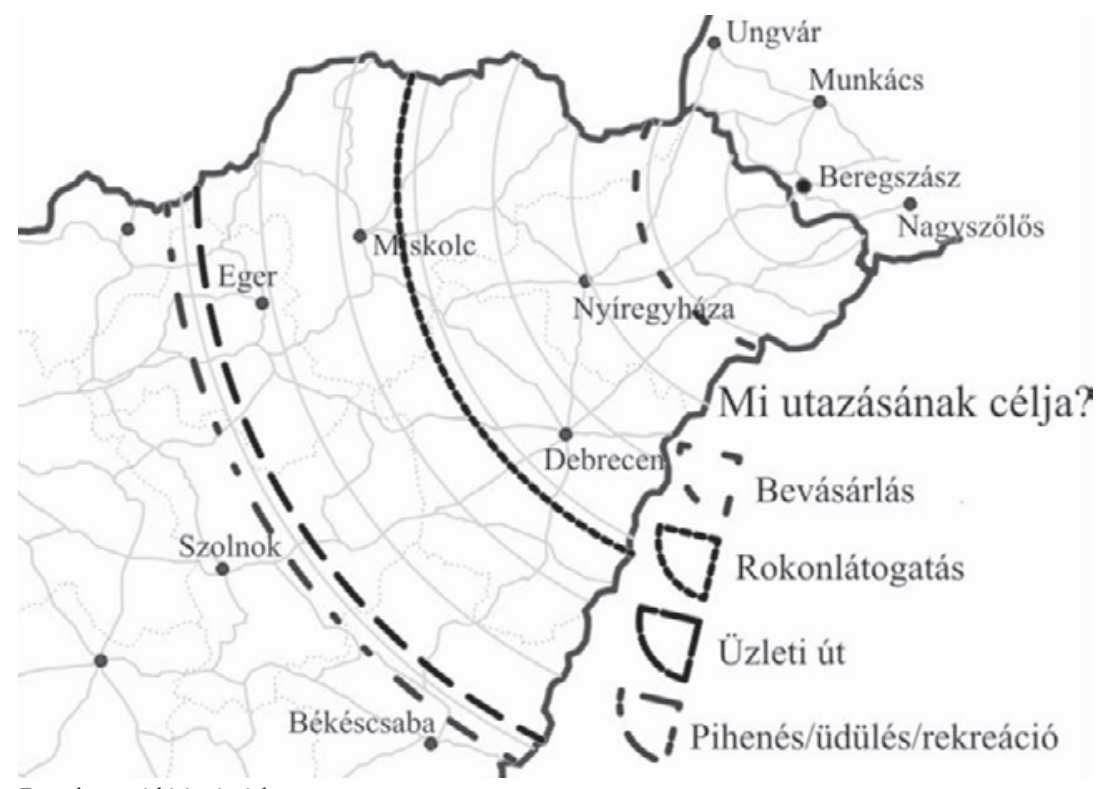

Forrás: saját kutatás. 
térnek leggyakrabban vissza, valamint az is megállapítható, hogy a kifejezetten üzemanyag-vásárlásért érkezők aránya a határ közvetlen közelében jóval magasabb, a távolság növekedésével pedig csökken ${ }^{6}$.

Az elköltött pénz mennyisége átlagosan 38 ezer Ft volt, de lényeges különbséget tapasztaltam a 2006-os minta (44 ezer Ft) és a 2007-es minta (32 ezer Ft) adatai között. Mindez jelzi a térség bevásárlóturizmusának 2007-ben jelentkező visszaesését, amit az árak közötti különbség csökkenése idézett elő. Az elköltött pénz mennyisége alapján a rokonlátogatóktól jól elkülönülnek az üzleti, pihenési, üdülési céllal érkező vendégek. Esetükben az átlagos összeg duplája a jellemző. A felmérésből kiderül, hogy a rokonlátogatási céllal érkezők költik a legkevesebb pénzt egy-egy kárpátaljai utazás alkalmával (Berghauer 2009).

A térség bevásárlóturizmusának sajátos vonása, hogy az idelátogató magyarországi vendégek túlnyomó többsége (86\%) a pénzváltást feketéző „valutásoknál" oldja meg, annak ellenére, hogy az utóbbi néhány évben a bankok száma a vidék városaiban megsokszorozódott. Hasonló specifikumként kezelhetjük a határátlépés idejére vonatkozó válaszokat. Azok a személyek, akik gyakrabban járnak át, általában kevesebb időt írtak be, mint a távolabbról érkező személyek. Ennek magyarázata, hogy a gyakrabban átjáró személyek rutinosabbak, tájékozottabbak azzal kapcsolatban, hogy mikor van nagyobb forgalom, így igyekeznek elkerülni azt. A mintában szereplő személyek a vizsgált időszakban átlagosan 2-3 órában adták meg a határátlépés idejét.

A vizsgálatok alapján elmondható, hogy Kárpátalján a bevásárlóturizmus „klasszikus” vonásai kimutathatók, de az 5-6 évvel ezelőtti időszakhoz képest csökkent e tevékenység volumene. Az utóbbi években Kárpátalján a változó ár/árfolyam-viszonyoknak köszönhetően a bevásárlóturizmus stabil alapját egyértelmủen az üzemanyag képezi. A bevásárlóút inflációra, árfolyamváltozásra nagyon érzékeny turisztikai termék, így az utazások iránya és volumene rövid távon is gyorsan változik. Ennek köszönhető, hogy a bevásárlóturizmus szempontjából a kárpátaljai lakosság számára Magyarország ismét érdekessé vált. Elsősorban a forint „gyenge” időszakában érvényesül ez, és műszaki cikkek, akciós termékek vásárlásában ölt testet, ami általában áfa-visszaigényléssel is párosul.

A Kárpátalján 2004 után kibontakozó bevásárlóturizmus gazdasági szempontból ösztönzőleg hatott a határ menti, periferikus területek kereskedelmi hálózatának fejlődésére, és a korábban erős munkaerő-felesleggel rendelkező terület lakosságának megélhetést is kínált helyben. A bevásárlóturizmus a "valós" turisztikai termékekre is gyakorolt némi vonzóhatást, mivel jelentosen csökkentette a környező országok lakosságának negatív véleményét Kárpátaljáról. Ebben az időszakban a magyarországi médiában megjelent sajtóhírek úgy mutatták be a határ menti területeket, mint ahová már el lehet utazni, sőt megéri elutazni, ezzel is csökkentve az ország és a megye erősen negatív idegenforgalmi imázsát. 


\section{A Kárpátaljára irányuló VFR-turizmus}

A határ menti térség idegenforgalmának legfontosabb szabadidős turisztikai motivációja (mind a magyar, mind az ukrán oldalon) a rokonok, barátok, ismerősök meglátogatása (VFR-turizmus). Alapját a határ két oldalán élő magyar lakosság szoros kapcsolati rendszere képezi. Kárpátalján a többségében magyar ajkúak által lakott települések a magyar határ mentén, 20-25 km-es sávban helyezkednek el. A kutatások egyértelműen bebizonyították a rokon, barát, ismerős motiválta utazások erős etnikai mivoltát (Dancs 2003). A magyar-ukrán-határ mentén élő lakosság közel 3/4-e rendelkezik határon átnyúló kapcsolatokkal, és ezeket rendszeresen ápolja. A nemzetiségi alapokra való tekintettel ezeket a kapcsolatokat határon átnyúló magyar-magyar-kapcsolatoknak is tekinthetjük, amelyek kárpátaljai aspektusai a megye turizmusának szempontjából is értékesek.

A rokon, barát, ismerős meglátogatása céljából érkező magyar állampolgárok többsége (5/6-a) kifejezetten rokonlátogatás céljával érkezik, a nem rokoni jellegü kapcsolatok ápolására irányuló érkezések másodlagosnak tekinthetők. A meglátogatott személyek közül az esetek 2/3-ában közvetlen rokoni kapcsolatokról beszélhetünk (szülő, testvér, nagyszülő).

A Kárpátaljára ilyen motivációval látogató magyarországi turisták 1/3-a negyedéves gyakorisággal érkezik erre a vidékre, míg kisebb számban tapasztalható a havi, a félévi, valamint az éves gyakoriság (3. ábra). Azokra a látogatókra, akik heti rendszerességgel jönnek $(9,8 \%)$ jellemző, hogy a határ közelében élnek, és gyakori másodlagos (vagy esetleg elsődleges) úticéljuk a bevásárlás. A legnagyobb küldőterület Magyarországon Budapest (29,5\%). A

3. ábra: A Kárpátaljára rokon, barát, ismerős meglátogatása céljával utazó magyar állampolgárok érkezésének gyakorisága

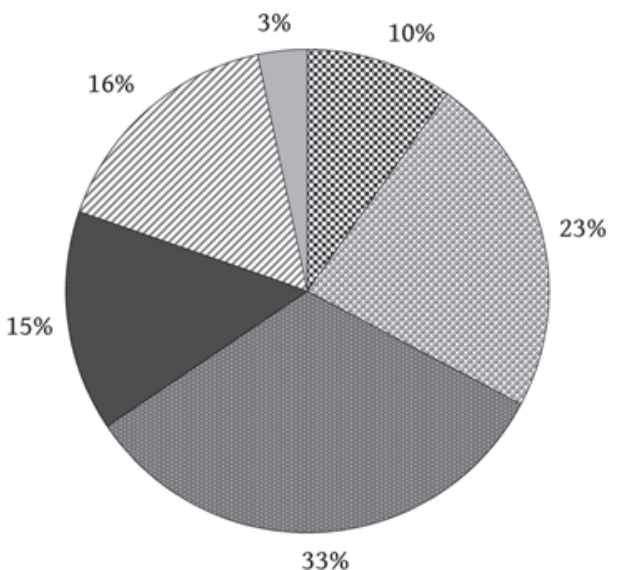

Q Hetente

B Havonta

줄 Negyedévente

Félévente

『 Évente

$\square$ Ritkábban

Forrás: Bolyog 2009 alapján saját szerkesztés. 
többi települést (Debrecent (6,6\%), Leveleket és Mátészalkát (4,9-4,9\%)) kisebb lélekszáma miatt ritkábban nevezik meg (Bolyog 2009), annak ellenére, hogy közelebb van Kárpátaljához.

A Kárpátaljára rokon, barát, ismerős meglátogatása céljával érkező magyar állampolgárok gyakorlatilag nem használják a megye turisztikai infrastruktúráját. Ez nem csak szállásköltségeiket érinti: alacsony az étkezésre és szórakozásra elköltött pénz aránya is, hiszen ezek együttesen sem érik el költségeik 1/5-ét. A költési struktúra sajátos eleme, hogy a vásárlásra fordított összeg a legnagyobb tétel (44\%), így gyakorlatilag a vendégek egy része már megfelel a bevásárlóturista-kategóriának is ${ }^{7}$.

Az ideérkező személyek jól érzik magukat Kárpátalján, ami nem véletlen, hiszen a megkérdezettek több mint fele a mai Ukrajna területén született. A határ menti magyar településeket látogató VFR-turisták számára a legfontosabb vonzerő természetesen a rokoni, baráti kapcsolatok ápolása. Jellemző, hogy pozitívan ítélik meg Kárpátalját (a korábban vizsgált bevásárlóturisták esetében jóval vegyesebbek voltak a vidékkel kapcsolatos vélemények), mivel elmondásuk alapján kellemes a környezet, nyugodt az élet, és nagyra értékelik a megye természeti és kulturális vonzerőit, amelyek közül a legtöbbet ismerik vagy személyesen látták is (3. táblázat).

3. táblázat: A válaszok megoszlása a "Mennyire ismeri Kárpátalja turisztikai látnivalóit?" kérdésre

\begin{tabular}{lccc} 
& & & (százalék) \\
\hline Turisztikai látnivalók & Személyesen látta & Hallott róla & Egyik sem \\
\hline Munkácsi vár & 68,9 & 26,2 & 4,9 \\
Ungvári vár & 55,7 & 37,7 & 6,6 \\
Vereckei-hágó & 52,5 & 44,3 & 3,3 \\
Szinevéri-tó & 49,2 & 39,3 & 11,5 \\
Huszti vár & 36,1 & 52,5 & 11,5 \\
A Tisza forrásvidéke & 27,9 & 52,5 & 19,7 \\
Hoverla & 21,3 & 68,9 & 9,8 \\
\hline
\end{tabular}

Forrás: Bolyog 2009 alapján saját szerkesztés.

Az ilyen jellegű utazások hosszú távon is képesek vonzást gyakorolni, de nem tartoznak a kifejezetten desztinációfejlesztő turisztikai tevékenységek körébe. A résztvevők kevés pénzt költenek a célterület idegenforgalmi infra- és szuprastrukturáiban, hiszen még szállás, illetve étkezés esetén sem a hagyományos turisztikai szolgáltatásokat veszik igénybe. Potenciális turistáknak viszont mindenképpen megfelelnek, hiszen pozitív véleménnyel vannak a térségről, érzelmileg kötődnek Kárpátaljához, biztonságban érzik magukat itt. 


\section{A magyar határ mentén éló kárpátaljai lakosok utazási szokásainak vizsgálata kérdóíves felmérés alapján}

Kárpátalja lakossága az elmúlt néhány évtizedben turisztikai szempontból inaktív volt. A szovjet időszakra jellemző zártság nem tette lehetővé a nyugati világban kialakult turizmusra jellemző szocializációs minták megszületését. A Szovjetunió széthullását követően Ukrajna egy-másfél évtizedre a gazdasági válság, sokak számára a létminimum alatti élet területévé vált. Az emberek többsége nem rendelkezett stabil anyagi bevétellel, nem volt meg az utazáshoz szükséges diszkrecionális jövedelem, és a motiváció jelentős részét is felemésztette a mindennapi megélhetés. A jelenleg kibontakozó gazdasági változások lassan megteremtik a lehetőségét annak, hogy a Kárpátalján, illetve a magyar-ukrán-határszakasz mentén élő lakosok utazási kedve javuljon. Az általam megvizsgált kárpátaljai települések lakosságát jellemző utazási szokások egyértelmüen rámutatnak arra, hogy e vidéken a belföldi és nemzetközi turizmus „kultúrájának” megjelenése még hosszú fejlődési út előtt áll.

A probléma feltárása érdekében kérdőíves felmérést végeztem a magyar határ mentén élő lakosok körében, amelyben kiemelt figyelmet fordítottam a magyarországi utazások feltárására. Hat kárpátaljai településen végeztem el a vizsgálatot (Gát, Gút, Nagybereg, Fornos, Szernye, Tiszakeresztúr) összesen 420 kérdőívet kitöltve, értékelve. A települések közös jellemzője, hogy lakosaik többsége magyar nemzetiségü, és valamennyi település Kárpátaljának közvetlenül a magyar-ukrán-határ menti sávjában helyezkedik el (4. táblázat).

A magyar határ mentén élő kárpátaljai lakosok utazási szokásaira rányomja bélyegét a határ közelsége és annak sajátos kapcsolatrendszere. Mindamellett a vidék lakosságáról elmondható, hogy viszonylag ritkán utazik. A megkérdezettek több mint fele az utóbbi félévben nem mozdult ki megszokott életteréből, nem vett részt utazáson. Ismerve a régió gazdasági mutatóit, mindez nem okoz meglepetést (a havi nettó átlagkereset kb. 26-32 ezer forintnak felel meg). A nagyobb számú utazás kezdeményezésére még nem áll a lakosság rendelkezésére a szükséges jövedelem, és elsősorban a szabadidőhöz kapcsolódó tevékenységek maradnak el. Amennyiben a megkérdezettek utazási gyakoriságát vizsgáljuk, legtöbben az évente (38\%) és az ennél ritkábban (28\%) utazók vannak (4. ábra). A gyakran útra kelők arányának vi-

4. táblázat: A felmérésben szereplő települések fontosabb adatai

\begin{tabular}{llcc}
\hline \multicolumn{1}{c}{ Település } & Közigazgatási egység & Lélekszám, fö & Ebböl magyar, \% \\
\hline Gát & Beregszászi járás & 3122 & 82,0 \\
Gút & Beregszászi járás & 1353 & 96,0 \\
Nagybereg & Beregszászi járás & 2540 & 79,0 \\
Fornons & Munkácsi járás & 1515 & 97,0 \\
Szernye & Munkácsi járás & 1979 & 85,4 \\
Tiszakeresztúr & Nagyszőlősi járás & 927 & 74,1 \\
\hline
\end{tabular}

Forrás: Molnár J., Molnár D. I. 2005 alapján saját szerkesztés. 
4. ábra: A Kárpátalja határ menti területén élő felnőtt lakosok utazásainak gyakorisága

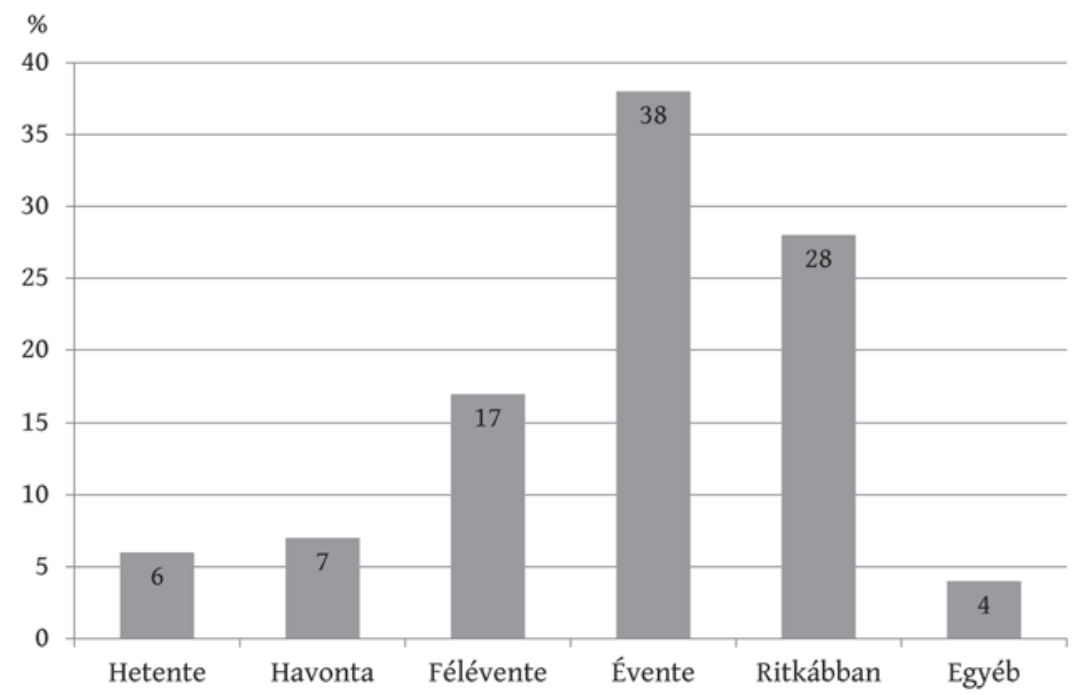

Forrás: saját kutatás.

szonylag magas volta - hetente $6 \%$, havonta $7 \%$ - elsősorban a határ közelségéből (rokonlátogatás, munkalehetőség keresése) fakad. Az utazások lebonyolításának időszaka nyári túlsúlyt mutat (69\%), amelyet az évszaktól független utazások száma (13\%) követ.

A magyar-ukrán-határ mentén élő kárpátaljai lakosok magyarországi utazásaik alkalmával célként általában két dolgot jelöltek meg: rokon, barát, ismerős meglátogatását (33\%), illetve munkalehetőség keresését (19\%) (5. táblázat). A többi utazási cél - gyógyüdülés, természeti és építészeti látnivalók megtekintése, falusi üdülés, túrázás, kutatómunka/konferencia - egyenként $10 \%$ alatt marad. A 13\%-ot képező egyéb utazási cél között is elsősorban munkával vagy más üzleti tevékenységgel, illetve vásárlással

5. táblázat: A magyar-ukrán-határ mentén élő kárpátaljai lakosok magyarországi utazásainak céljai

\begin{tabular}{lc}
\hline \multicolumn{1}{c}{ Az utazás célja } & Megoszlás, \% \\
\hline Rokon, barát, ismerōs meglátogatása & 33 \\
Munkalehetőség keresése & 19 \\
Természeti látnivalók megtekintése & 9 \\
Építészeti látnivalók megtekintése & 9 \\
Falusi üdülés & 6 \\
Túrázás & 6 \\
Kutatómunka/konferencia & 4 \\
Gyógyüdülés & 3 \\
Egyéb & 13 \\
\hline
\end{tabular}

Forrás: saját kutatás. 
kapcsolatos indítékok szerepeltek. Más területekre való utazásokkal összevetve egyrészt szembetűnő, hogy mennyire Magyarország-orientált a határ menti lakosság, másrészt a Kárpátokba, illetve az Ukrajna belső területeire irányuló utazások esetében sokkal kisebb a rokon, barát, ismerős meglátogatását célzó utazások aránya. Ezeknél a desztinációknál előtérbe kerülnek a területspecifikus úticélok. Így például a Kárpátok mint célterület elsősorban természeti látnivalói (39\%) és a túrázás (20\%) kapcsán jut szerephez.

A helyi lakosság lehetőségeit ismerve az sem meglepő, hogy többségük rövid ideig tartózkodik a meglátogatott területen: 25,3\% 1-2 napot, 21\% pedig egy napnál is kevesebbet. 17-18\% azoknak az aránya, akik 3-6 napot, illetve egy hetet töltenek távol otthonuktól. A két hétnél hosszabb ideig távolmaradók körében $(4,8 \%)$ feltűnően magas a munkavállalási céllal útra kelő személyek aránya. Ezeken belül a magyarországi utakat vizsgálva kitűnik, hogy a tartózkodás ideje hosszabb az átlagos utazási időnél. A többség (68\%) 3-6 napot tölt Magyarországon, és a két hétnél tovább maradó személyek aránya is magasabb, eléri a 12\%-ot. Mindez eltér az ukrán állampolgárok magyarországi utazási szokásaitól, ami a határ mentén élő magyar lakosság szoros anyaországi kapcsolataira és a gyakran előforduló (elsősorban mezőgazdasági) idénymunka-vállalásra vezethető vissza.

A megkérdezett személyek utazási szokásaira jellemzo, hogy 44\%-uk az utóbbi öt évben járt Magyarországon. Úticélként többen keresték fel Magyarországot, mint a Kárpátokat (26\%) és Ukrajna belső, Kárpátokon túli területeit (16\%) együttvéve. A felsoroltakon kívül célterületként előfordulnak még más, elsősorban szomszédos országok (Románia, Szlovákia, Lengyelország), illetve a kárpátaljai lakosok által kedvelt, kifejezetten üdülési, pihenési céllal felkeresett országok is (Törökország, Egyiptom, Tunézia, Horvátország), de ezek részesedése elenyésző.

Sajátos kép tárul elénk, amennyiben a határ menti lakosok utazásainak szervezési hátterét vizsgáljuk meg. Arra a kérdésre, hogy ki szervezte a szóban forgó személyek utazását, az esetek többségében azt a választ kaptuk, hogy azt vagy önállóan valósította meg (49\%), vagy rokon, barát, ismerős (29\%) szervezte (5. ábra). A szervezett keretek között (utazási iroda, turistaútszervező) történő magyarországi utazás a megkérdezettek válaszainak csak 2\%-át tette ki. Hasonló arányok jellemzik a határ menti lakosság Ukrajnán belüli utazásait is (önállóan $40 \%$, rokon, barát, ismerős által $24 \%$ szervezi utazásait), igaz valamivel magasabb (11\%) a munkahely által szervezett utak részesedése. A más országokba (Magyarország nem ide sorolandó) irányuló utazások - azon túl, hogy nem túl gyakran fordulnak elő - azzal is kitűnnek, hogy magasabb a szervezett keretek között utazók száma (44\%), igaz ennek fele nem hivatalos engedélyekkel rendelkező szervezés keretében történik.

Az utazás szervezéséhez hasonló módon zajlik a szálláshelyek megválasztása és az étkezéssel kapcsolatos kérdések megoldása is. Magyarországi utazás esetében rokonnál, barátnál vagy ismerősnél éjszakázik a megkérdezettek 
5. ábra: A határ menti lakosság utazásainak szervezője

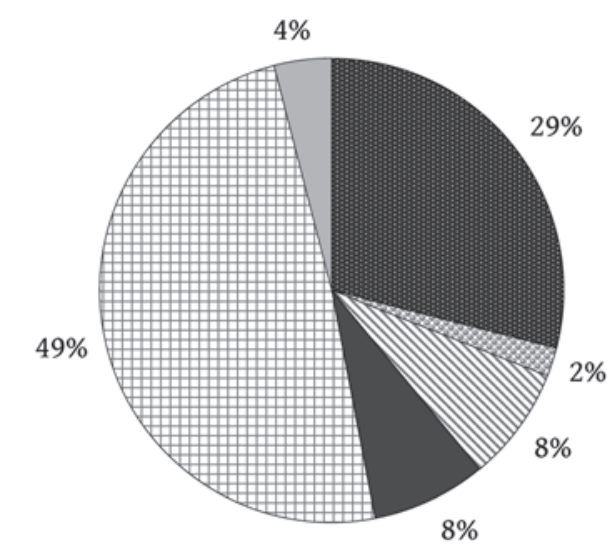

Rokon, barát, ismerős

圈 Utazási iroda, turistaút-
szervező

$\mathbb{Q}$ Nem hivatalos turistaútszervező

- Munkahely

$\boxplus$ Saját maga

Egyéb

Forrás: saját kutatás.

53,1\%-a. Magas a munkavállalással összefüggésbe hozható munkásszállón $(11,6 \%)$, illetve az iskolai kollégiumokban $(8,2 \%)$ való éjszakázás részesedése is. Szállodai tartózkodás csak az esetek 6,9\%-ban fordul elő. Az Ukrajnán belüli utazások alkalmával már alacsonyabb a rokon, barát és ismerős által nyújtott szállás szerepe $(22,6 \%)$, és alternatív lehetőségként megjelenik a vadkemping (18,5\%), valamint a hosszabb utazások alkalmával a szállodai elszállásolás (19\%). Más külföldi utazások során már az esetek 1/3-ban a szállodai éjszakázás szerepel az első helyen.

Az étkezést illetően hasonló helyzet áll elő, mint a szálláshelyeknél. A magyarországi utazások során a válaszok felében a rokonnál, barátnál vagy ismerősnél való étkezés szerepel, az éttermi koszt részesedése mindössze 9,3\%. A más területekre történő utazás során az étkezést illetően kiemelhetjük, hogy a Kárpátokba történő utazások alkalmával a hozott étel aránya meghaladja az 50\%-ot, ami a kisebb távolságok miatt egyáltalán nem meglepő.

A határ mentén élő kárpátaljai lakosok kevés visszatartó információt soroltak fel utazásaikat illetően. Ukrajna esetében elsősorban az infrastruktúrával és a közlekedéssel kapcsolatos hiányosságokat, észrevételeket helyezték előtérbe. Magyarország esetében - és ez meglehetősen sajátságos, különösen az utazási indítékokat ismerve - az ott élő emberek közömbössége jelent visszatartó tényezőt.

Az utazásoktól való távolmaradás okaira is kitért a felmérés. A kérdésre a megkérdezettek 2/3-a válaszolt (6. táblázat). A távolmaradás elsődleges oka, mint azt feltételeztem, elsősorban anyagi jellegű $(54,5 \%)$, továbbá magasnak mondható a szabadidő hiánya $(20,9 \%)$ miatt nem utazó személyek aránya is. Az egészségügyi okok megnevezése elsősorban az idősebb korosztályra volt jellemző. 
6. táblázat: Az utazásoktól való távolmaradás fő okának megoszlása

\begin{tabular}{lc|lc}
\hline \multicolumn{1}{c}{ Ok } & Megoszlás, \% & \multicolumn{1}{c}{ Ok } & Megoszlás, \% \\
\hline Anyagi & 54,5 & Nem szeret utazni & 3,7 \\
Szabadidő hiánya & 20,9 & Információhiány & 1,5 \\
Egészségügyi & 14,9 & Egyéb & 4,5
\end{tabular}

Forrás: saját kutatás.

A magyar-ukrán-határ mentén élő kárpátaljai lakosok magyarországi utazásai két fő motiváció körül forognak: rokon, barát, ismerős meglátogatása és a megélhetést elősegítő munkahely keresése. A bevásárlással kapcsolatos indítékok háttérben maradtak, de ezekről feltételezhetjük, hogy a határ közvetlen közelében (5-10 km) nagyobb jelentőséggel bírnak. A korlátozott anyagi lehetőségek arra ösztönzik a térség lakosságát, hogy utazásaik során racionális kompromisszumokat kössenek, így költségeik nagyobb részét (56\%) közvetlenül az útiköltségek, valamint a vásárlás teszi ki. Az attrakciókra és szórakozásra költött összeg aránya csak 15\%. A szállás, étkezés tekintetében felértékelt szerepet tölt be a rokon, barát, ismerős kapcsolatrendszere, és ami szintén specifikus a vidék lakosságának utazásai kapcsán, hogy utazásai nagyobb részét vagy önállóan, vagy a rokoni, baráti, ismerősi kör segítségét igénybe véve szervezi meg. Azok a turisztikai termékek, amelyek Magyarország turizmusának kínálatában vezető szerepet töltenek be - egészségturizmus, kulturális turizmus, falusi turizmus - magas színvonaluk ellenére egyelőre drágának bizonyulnak a határ közelében élő kárpátaljai lakosok számára.

\section{Összegzés}

A magyar-ukrán-határ menti területek lakosságának kapcsolata hosszabb távon is a ma tapasztalt utazási indítékok mentén fejlődik majd tovább. A kialakult bevásárlóturizmus irányát, intenzitását elsősorban a forint/hrivnya árfolyama, illetve az üzemanyag árában tapasztalt különbség határozza meg. A határforgalmat nagyban befolyásoló határátkelés és ellenőrzési rend további szigorodása a közeljövőben nem várható, hiszen az Európai Unió részéről 2004-ben áthelyezett schengeni-ellenőrzés további fokozása indokolatlan lenne, ukrán részről pedig a Labdarugó Európa-bajnokság rendezése kapcsán sokkal inkább a határforgalom gyorsítása várható el.

A VFR-turizmus tartós fennmaradásának alapját a határ két oldalán élő nemzetiségi alapú, szoros emberi kapcsolatok képezik. A határon átnyúló magyar-magyar-kapcsolatok fejlődését Magyarország részéről kormányzati szinten is támogatják. Fontos eszköze volt ennek a közelmúltban bevezetett magyarigazolvány és a vele járó utazási kedvezmények, a kishatárforgalom ismételt beindítása, az egyszerüsített vízumigénylés lehetőségének biztosítása, továbbá a kettős állampolgárság 2010-ben való bevezetése. Ugyanakkor, a je- 
lenben is jól érezhető, hogy a szűkös anyagi lehetőségek nagyban befolyásolják a határ menti kapcsolatok jellegét, az utazási motivációk és szokások alakulását. Másrészt jogosan feltételezhetjük, hogy a jövőben gazdasági növekedés vár a régióra, ami a lakosság diszkrecionális jövedelmének emelkedésével a szabadidős utazások számának növekedését idézi majd elő. Ennek tudatában célszerű az utazási szokások fejlődési irányát továbbformálni, alakítani akár kormányzati szinten, EU-s források felhasználásával. A közös nyelv és kulturális alapok, a szakmai programok a jelenben és a közeljövőben is mélyítik majd a kapcsolatokat. $\mathrm{S}$ mivel a jelentős helyismeret mindkét részről megvan, a térség jogosan számíthat a határ túloldalán lévő lakosság „valódi” turistaként való megjelenésére, ami által a határ menti periferikus területek felzárkózási esélyei javulhatnak.

\section{Jegyzetek}

1 Visiting Friends and Relatives - rokonok és barátok meglátogatása.

2 A rendszerváltást követő években az ukrán-magyar határ mentén élő kárpátaljai lakosok szükös anyagi lehetőségekkel rendelkeztek, ezért csencseléssel, csempészéssel egészítették ki háztartásaik bevételét. A többség a Magyarország piacain eladott „portéka” áráért az ország határain belül élelmiszert, használati, illetve Ukrajnában hiánycikknek számító termékeket vásárolt. A megkeresett pénz nagyobb részét Magyarország piacain és kiskereskedelmi egységeiben költötték el (Csite et al. 1995).

3 Magyarországon ebben az időben az ideiglenes rendszámtáblák „Z” betűvel kezdődtek. Ebből származik a „Z-turizmus” kifejezés.

4 A mintavétel 2006-2007 során több lépésben történt, és helyszínéül Beregszászt választottam, mivel lélekszáma, határhoz való közelsége, illetve nemzetiségi összetétele alapján kedvezőbbek az adottságai bármely más szóba jöhető településnél. A felmérés során 345 kérdőívet töltöttek ki.

5 Korábban hasonló kutatást végeztek a határ magyarországi szakaszán, ahol a Magyarországra irányuló bevásárlóturizmus sajátosságait vizsgálták (Gyuricza 2002, Michalkó 2002).

6 Az üzemanyag határ menti keresletének növekedését az ukrajnai olajtársaságok is érzékelték. A Beregsurány-Asztély határátkelőt elhagyva a határtól 9 km-re lévő Beregszászig 11 benzinkutat találunk, illetve további 11 benzinkút helyezkedik el a város határain belül.

7 „Az a turista, akinek költési struktúrájában az áruvásárlásra fordított összeg eléri a teljes költség felét, bevásárlóturistának nevezhető" (Michalkó 2004a, 14.).

\section{Irodalom}

Balcsók I., Dancs L. (2001): A határon átnyúló kapcsolatok lehetőségei Magyarország egyik leendő schengeni határán. In: Dormány G., Kovács F., Péti M., Rakonczai J. (szerk.): A földrajz eredményei az új évezred küszöbén. Magyar Földrajzi Konferencia. SZTE TTK Természeti Földrajzi Tanszék, Szeged (CD-ROM)

Berghauer S. (2008a): Cross border relationship and tourism. Shopping tourism in Beregszász. In: Soós K., Orosz I. (szerk.): Acta Beregsasiensis. A II. Rákóczi Ferenc Kárpátaljai Magyar Főiskola tudományos közleményei, 2008. július 2., Ungvár, 214-222. 
Berghauer S. (2008b): Bevásárlóturizmus Kárpátalján. Закупівельний туризм на Закарпатті. In: Láczay M., Balogh Z. (szerk.): A határon átívelő együttmüködés perspektívái - a munkaerőpiac az Európai Unió határán. Nyíregyházi Főiskola Gazdasági és Társadalomtudományi Kar, Nyíregyháza, 117-146.

Berghauer S. (2008c): Határmentiség és turizmus. Bevásárlóturizmus Beregszászon. In: Szónoky A. G. (szerk.): Magyarok a Kárpát-medencében. Nemzetközi Földrajzi Konferencia, 2008. március 6., Szeged, 455-463.

Berghauer S. (2009): Прикордонне розташування і туризм. Шоп-туризм на Закарпатті. In: Географія і туризм: європейський досвід. Матеріали III Міжнародної конференції. Львів, $14-18$.

Bolyog B. (2009): Rokonlátogatás céllal Kárpátaljára érkező magyar állampolgárok utazási szokásainak vizsgálata kérdőives felmérés alapján. II. Rákóczi Ferenc Kárpátaljai Magyar Főiskola Földtudományi Tanszék. Szakdolgozat. Beregszász

Csite A., Ivaskin A., Orbán S., Varga S. (1995): Csencselők és maffiózók Kárpátalján. Szabolcs-Szatmár-Beregi Szemle, 252-260.

Dancs L. (2003): Turizmus és üdülési szokások Kárpátalja határ menti településein a harmadik évezred küszöbén. In: Süli-Zakar I. (szerk.): Határok és határ mentiség az átalakuló Közép-Európában. Debrecen, $169-178$.

Donka A., Gyuricza L. (2002): Az ukrán-magyar határtérség magyar oldalának területileg differenciált fejlesztési lehetőségei. In: Szónokyné Ancsin G. (szerk.): Határok és az Európai Unió. Nemzetközi földrajzi konferencia, 2002. november 29-december 1. SZTE TTK Gazdaság- és Társadalomföldrajzi Tanszék, Szeged, 223-231.

Gyuricza L. (1996): A szlovén-magyar határforgalom változása a kilencvenes években, s ennek hatása Nyugat-Zalára. Muratáj, 86-95.

Gyuricza L. (2002): A bevásárlóturizmus tündöklése és hanyatlása Lentiben. In: Füleky Gy. (szerk.): A táj változásai a Kárpát-medencében. Az épített környezet változása Gödöllőn, 236-241.

Gyuricza L. (2008): A turizmus nemzetközi földrajza. Egyetemi tankönyv, Dialóg Campus, Budapest-Pécs

Kárpátalja - Szanatóriumok és turizmus (Закарпаття - Санаторії та туризм) (2010): Статистичний збірник (Statisztikai évkönyv), Ужгород

Michalkó G. (2002): Országkép és kiskereskedelem - A külföldi turisták szabadidős vásárlásai a magyarországi idegenvezetők szemével. Turizmus Bulletin, 22-29.

Michalkó G. (2004): A bevásárlóturizmus. Kodolányi János Főiskola, Székesfehérvár

Molnár J., Molnár D. I. (2005): Kárpátalja népessége és magyarsága a népszámlálási és népmozgalmi adatok tükrében. A Kárpátaljai Magyar Pedagógusszövetség Tankönyv- és Taneszköztanácsa, PoliPrint Kft., Ungvár

KSH (2005): Turisztikai statisztikai évkönyv, Budapest

KSH (2006): Turisztikai statisztikai évkönyv, Budapest

KSH (2007): Turisztikai statisztikai évkönyv, Budapest 


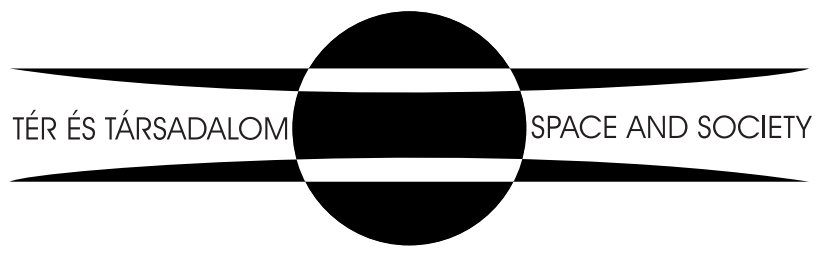

